\title{
Report on the FY18 Creep Rupture and Creep-Fatigue Tests on the First Commercial Heat of Alloy 709
}

Project No. 23747, 29412

Michael McMurtrey

The INL is a

U.S. Department of Energy

National Laboratory

operated by

Battelle Energy Alliance

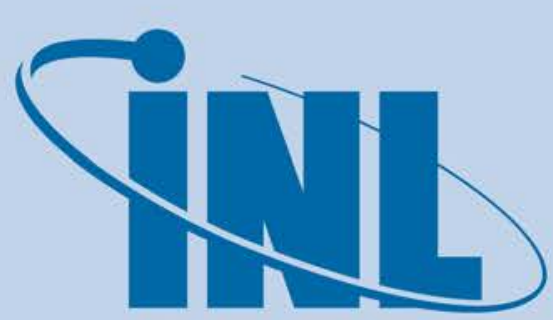

Idaho National Laboratory
August 2018

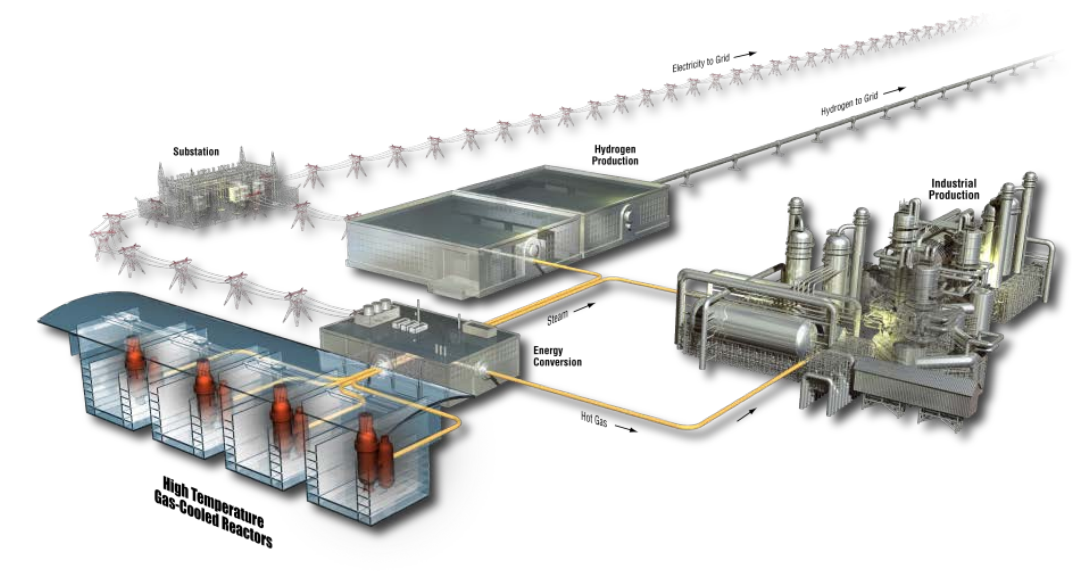




\section{DISCLAIMER}

This information was prepared as an account of work sponsored by an agency of the U.S. Government. Neither the U.S. Government nor any agency thereof, nor any of their employees, makes any warranty, expressed or implied, or assumes any legal liability or responsibility for the accuracy, completeness, or usefulness, of any information, apparatus, product, or process disclosed, or represents that its use would not infringe privately owned rights. References herein to any specific commercial product, process, or service by trade name, trade mark, manufacturer, or otherwise, does not necessarily constitute or imply its endorsement, recommendation, or favoring by the U.S. Government or any agency thereof. The views and opinions of authors expressed herein do not necessarily state or reflect those of the U.S. Government or any agency thereof. 
INL/EXT-18-46140

Revision 0

\title{
Report on the FY18 Creep Rupture and Creep-Fatigue Tests on the First Commercial Heat of Alloy 709
}

\author{
Michael McMurtrey
}

August 2018

\begin{abstract}
Idaho National Laboratory
INL ART Program

Idaho Falls, Idaho 83415
\end{abstract}

http://www.inl.gov

Prepared for the

U.S. Department of Energy

Office of Nuclear Energy

Under DOE Idaho Operations Office

Contract DE-AC07-05ID14517 

INL ART Program

\title{
Report on the FY18 Creep Rupture and Creep-Fatigue Tests on the First Commercial Heat of Alloy 709
}

\author{
INL/EXT-18-46140 \\ Revision 0
}

August 2018
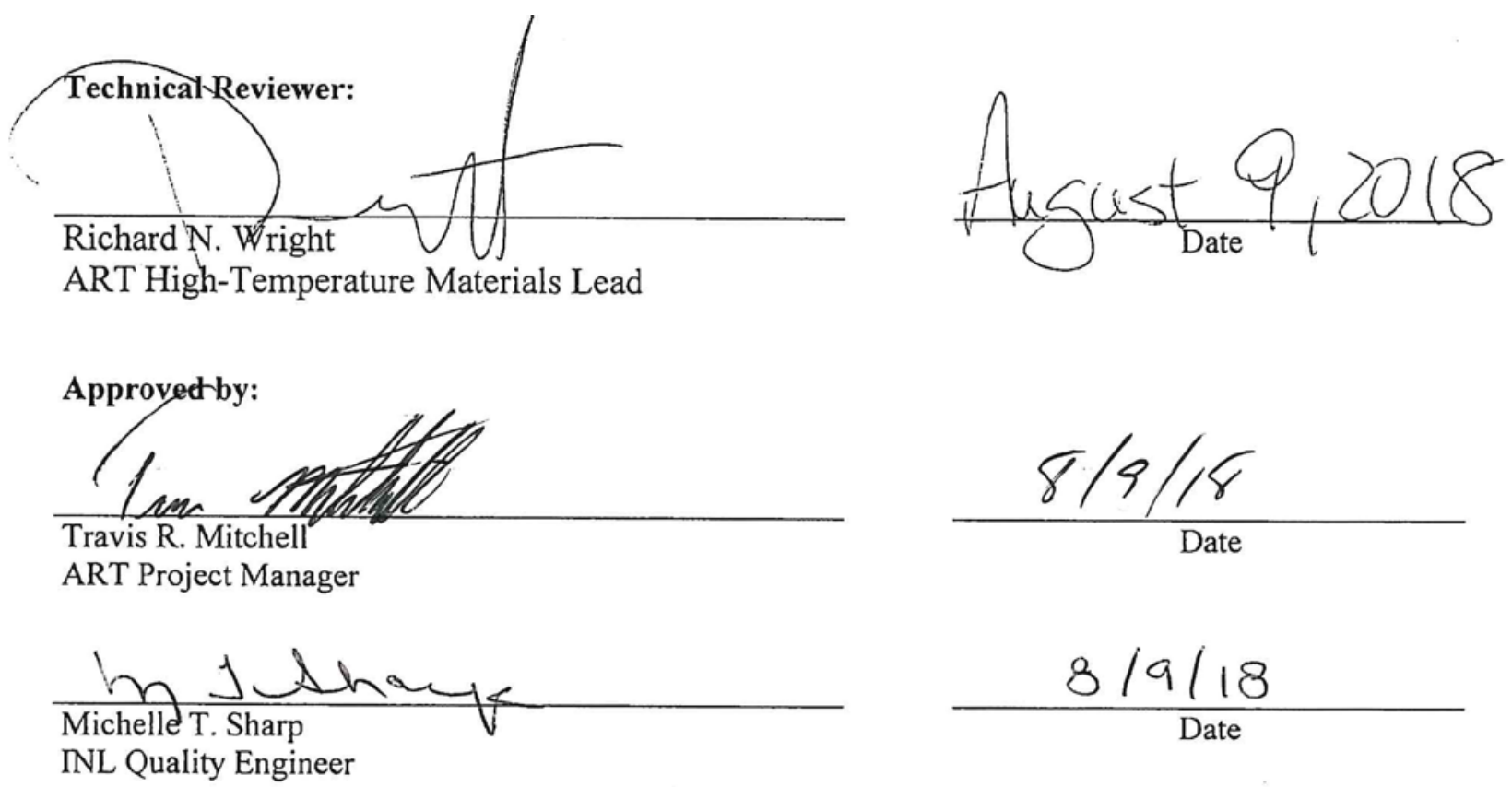



\begin{abstract}
Creep, fatigue, and creep-fatigue tests were performed on the commercial scale G.O. Carlson plate of Alloy 709 (ID 58776-4). The Alloy 709 heat was first processed using the argon oxygen decarburization process (AOD). A portion of the heat was then refined using electro-slag remelting (ESR). Finally, a portion of the ESR ingot underwent a homogenization heat treatment (ESR+HOMO). The three ingots were hot rolled into plates and each was further divided into three sections for different solution annealing temperatures $\left(1050,1100\right.$ and $\left.1150^{\circ} \mathrm{C}\right)$. The effects of processing method and solution annealing temperature were studied in FY-18 to inform best procedures for the second heat. The solution annealing temperature of $1050^{\circ} \mathrm{C}$ was found to be unacceptable due to the grain size being smaller than allowed by the specifications. This material also had generally poor creep properties. Annealing at 1100 and $1150^{\circ} \mathrm{C}$ resulted in material with grain size that met the specifications. Both argon oxygen decarburization and electro-slag remelting were found to have desirable properties, and the homogenization heat treatment was found not significantly to improve mechanical properties.
\end{abstract}




\section{ACRONYMS}

$\begin{array}{ll}\text { ANL } & \text { Argonne National Laboratory } \\ \text { AOD } & \text { argon oxygen decarburization } \\ \text { ART } & \text { Advanced Reactor Technologies } \\ \text { ASME } & \text { American Society of Mechanical Engineers } \\ \text { ASTM } & \text { ASTM, International (formerly, the American Society for Testing and Materials) } \\ \text { ATS } & \text { Applied Test Systems } \\ \text { ESR } & \text { electro-slag remelting } \\ \text { HOMO } & \text { homogenized } \\ \text { INL } & \text { Idaho National Laboratory } \\ \text { LVDT } & \text { linear variable differential transformer } \\ \text { S/A } & \text { solution anneal }\end{array}$




\section{CONTENTS}

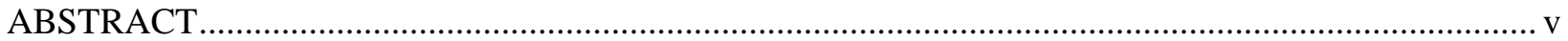

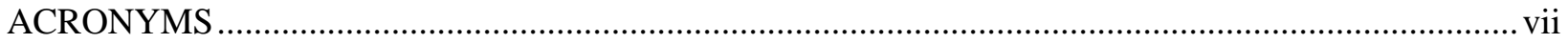

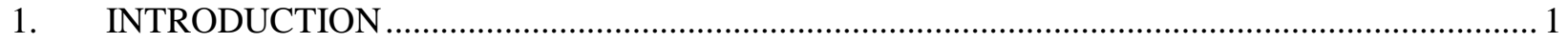

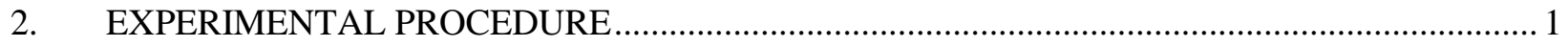



3.1 Creep Rupture Results ............................................................................................... 2

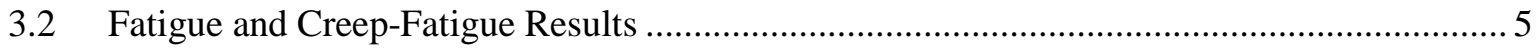

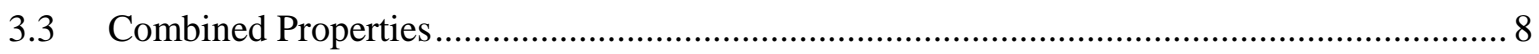

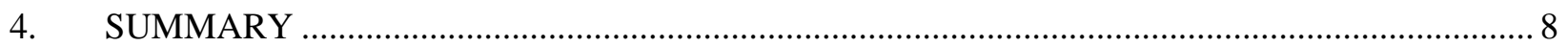

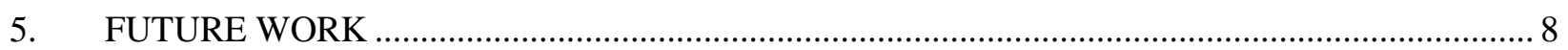

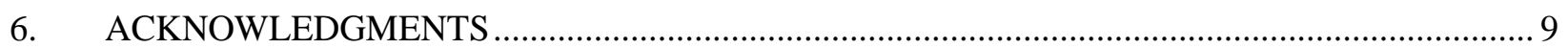

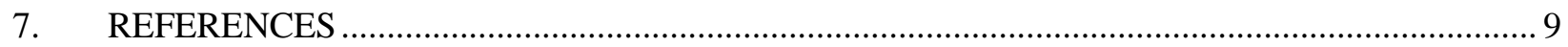

\section{FIGURES}

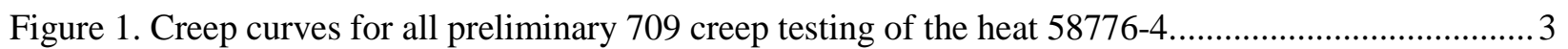

Figure 2. Example of a ruptured creep specimen. This is from the AOD S/A $1150^{\circ} \mathrm{C}$ plate....................... 3

Figure 3. Example micrographs of the AOD S/A $1050^{\circ} \mathrm{C}$ plate. Grain distribution was bimodal, with both large grains and very small grains present.........................................................

Figure 4. Example micrograph of the AOD S/A $1100^{\circ} \mathrm{C}$ plate. Grains were generally uniform in size.

Figure 5. Example micrographs of the AOD S/A $1150^{\circ} \mathrm{C}$ plate. In general, grains were uniform in size, with the occasional large grain as seen in the left micrograph......................................... 5

Figure 6. Examples of hysteresis loops. Fatigue (left) and creep-fatigue (right) mid-life hysteresis

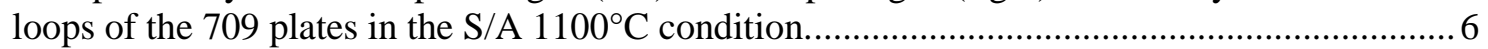

Figure 7. Fatigue (a,c,e) and creep-fatigue (b,d,f) curves for the S/A $1050^{\circ} \mathrm{C}(\mathrm{a}, \mathrm{b}), 1100^{\circ} \mathrm{C}(\mathrm{c}, \mathrm{d})$ and $1150^{\circ} \mathrm{C}(\mathrm{e}, \mathrm{f})$ conditions.

\section{TABLES}

Table 1. G.O. Carlson alloy 709 plate composition, as measured from the AOD plate............................. 1

Table 2. Summary of creep results for the preliminary creep testing of the heat $58776-4$......................... 2

Table 3. Fatigue and creep-fatigue summary for Carlson alloy 709 testing. ............................................. 6

Table 4. Summary of all mechanical testing. Replicate tests are averaged to one value............................. 8 


\section{Report on the FY18 Creep Rupture and Creep-Fatigue Tests on the First Commercial Heat of Alloy 709}

\section{INTRODUCTION}

Previous work on advanced austenitic steels led to the selection of Alloy 709 for development as an available fast-reactor structural material. ${ }^{1}$ Alloy 709 is a $25 \mathrm{Cr} 20 \mathrm{Ni}$ austenitic stainless steel similar to Type 316, but with improved elevated-temperature properties. The improved properties have the potential to improve the economics of the reactor by allowing for longer component lifetimes and less required component thickness. Following the down selection to Alloy 709, a number of laboratory-scale heats of the alloy were made to refine processing conditions and heat treatments to obtain the desired hightemperature mechanical properties. ${ }^{2,3,4,5,6,7,8,9}$ Based on these results, an industrial-scale heat of Alloy 709 was commissioned from G.O. Carlson. The composition of the heat is shown in Table 1.

Table 1. G.O. Carlson alloy 709 plate composition, as measured from the AOD plate.

\begin{tabular}{|c|c|c|c|c|c|c|c|c|c|c|c|c|c|c|c|}
\hline & $\mathrm{C}$ & $\mathrm{Mn}$ & $\mathrm{Si}$ & $\mathrm{P}$ & $\mathrm{Cr}$ & $\mathrm{Ni}$ & $\mathrm{Mo}$ & $\mathrm{N}$ & $\mathrm{Cb}$ & $\mathrm{Ti}$ & $\mathrm{Cu}$ & $\mathrm{Co}$ & $\mathrm{Al}$ & $\mathrm{B}$ & $\mathrm{Fe}$ \\
\hline Composition (wt\%) & 0.07 & 0.91 & 0.44 & 0.014 & 19.93 & 24.98 & 1.51 & 0.148 & 0.26 & 0.04 & 0.06 & 0.02 & 0.02 & 0.0045 & $\mathrm{Bal}$. \\
\hline
\end{tabular}

The G.O. Carlson heat (58776-4) was divided into nine smaller portions, each with a unique processing history. Three processing procedures were applied: argon oxygen decarburization (AOD), electro-slag remelting (ESR) and homogenized after the ESR process (ESR+HOMO). Each of these was solution annealed (S/Aed) at three different temperatures $\left(1050^{\circ} \mathrm{C}, 1100^{\circ} \mathrm{C}\right.$ and $\left.1150^{\circ} \mathrm{C}\right)$, resulting in the desired nine plates with unique processing histories. The AOD process is common in steelmaking as the first step in alloy melting. The addition of an ESR step has become common commercial practice and is thought to better control impurity content in some circumstances, but the additional processing step adds to cost. High temperature homogenization was carried out to reduce segregation in the ESR ingot prior to rolling in the hope that this would reduce banding in the microstructure after solution treatment. The range of solution annealing temperatures was selected because it is thought that a $100^{\circ} \mathrm{C}$ temperature range is consistent with commercial practice.

Creep and cyclic testing was carried out to characterize the creep, fatigue, and creep-fatigue behavior of each processing condition for the Carlson Alloy 709 heat. The cyclic testing was conducted primarily at a single fatigue and creep-fatigue condition, which was at $650^{\circ} \mathrm{C}$ and $1.0 \%$ total strain $( \pm 0.5 \%$ strain). For creep-fatigue, a 30-minute hold time at peak tensile strain was introduced. Creep testing was performed at $600^{\circ} \mathrm{C}$ with $330 \mathrm{MPa}$ applied stress. The goal of this work was to determine the allowable methods of producing alloy 709 for use in the proposed American Society of Mechanical Engineers (ASME) Boiler and Pressure Vessel Code Case.

\section{EXPERIMENTAL PROCEDURE}

Fatigue and creep-fatigue tests at $650^{\circ} \mathrm{C}$, primarily at $1.0 \%$ total strain and a 30 -minute peak tensilestrain hold (creep-fatigue only), were conducted on specimens from each of the nine plate conditions. Fully reversed, strain-controlled, low-cycle triangular waveform fatigue and creep-fatigue testing were conducted at a strain rate of $10^{-3} / \mathrm{s}$ in laboratory air using servo-hydraulic test frames in accordance with PLN-3346. ${ }^{10}$ The creep-fatigue tests followed a similar waveform as the standard fatigue test, with the addition of a strain-controlled hold time at peak tensile strain. Cycles to failure, $\mathrm{N}_{\mathrm{f}}$, is defined as a decrease in the peak tensile stress of $25 \%$ from the point at which the peak stress initially deviates from a steadily declining value. Creep and creep-fatigue testing followed ASTM, International, Standards E606 and E2714, respectively. ${ }^{11,12}$ 
Creep rupture testing was performed at $600^{\circ} \mathrm{C}$ and $330 \mathrm{MPa}$ in Applied Test Systems (ATS) creep frames. Testing was typically performed on creep frames with a 20:1 lever arm that multiplied the applied load onto the specimen, allowing for the high applied stresses. All creep testing was performed in accordance with PLN-3386. ${ }^{13}$ During the test, specimen elongation was measured with an extensometer connected to linear variable differential transformers (LVDTs) or to Heidenhain displacement length gauges. Following the specimen rupture, a time to rupture was recorded (time elapsed since the start of test) and the specimen length and diameter were measured and compared to pretest measurements to determine actual elongation and reduction in area, in accordance with ASTM E139. ${ }^{14}$

\section{RESULTS}

\subsection{Creep Rupture Results}

A total of 18 creep tests were performed for this preliminary study, two at each of the processing conditions and S/Aing temperatures. Test conditions were determined so that the expected creep rupture life was 1000 hours, based on previous work. Five of these tests are ongoing, as of the date of this report. These results are summarized in Table 2, with the creep curves shown in Figure 1. Specimens generally were found to rupture in the center of the gauge, as shown in the example specimen in Figure 2.

Table 2. Summary of creep results for the preliminary creep testing of the heat 58776-4.

\begin{tabular}{|c|c|c|c|c|c|c|c|}
\hline $\begin{array}{l}\text { Processing } \\
\text { condition }\end{array}$ & $S / A$ & $\begin{array}{c}\text { Temp } \\
C\end{array}$ & $\begin{array}{l}\text { Stress, } \\
\mathrm{MPa}\end{array}$ & $\begin{array}{l}\text { Rupture } \\
\text { time, hr }\end{array}$ & $\begin{array}{c}\text { Strain } \\
\text { (extensometer), \% }\end{array}$ & $\begin{array}{c}\text { Strain (post-test } \\
\text { measurement), } \%\end{array}$ & $\begin{array}{l}\text { Reduction in } \\
\text { area, } \%\end{array}$ \\
\hline \multirow{6}{*}{ AOD } & \multirow{2}{*}{1050} & 600 & 330 & 701 & 12.83 & 14.06 & 17.77 \\
\hline & & 600 & 330 & 638 & 11.12 & 12.77 & 16.52 \\
\hline & \multirow{2}{*}{1100} & 600 & 330 & 1785 & 14.56 & 17.38 & 24.45 \\
\hline & & 600 & 330 & 1626 & 15.61 & 18.54 & 23.08 \\
\hline & \multirow{2}{*}{1150} & 600 & 330 & 2712 & 18.87 & 21.54 & 29.46 \\
\hline & & 600 & 330 & 3296 & 12.37 & 15.74 & 24.67 \\
\hline \multirow{6}{*}{ ESR } & \multirow{2}{*}{1050} & 600 & 330 & 1538 & 30.99 & 26.17 & 44.07 \\
\hline & & 600 & 330 & 1589 & 29.87 & 25.36 & 38.03 \\
\hline & \multirow{2}{*}{1100} & 600 & 330 & 2386 & 21.12 & 21.32 & 33.90 \\
\hline & & 600 & 330 & \multicolumn{4}{|c|}{ ONGOING } \\
\hline & \multirow{2}{*}{1150} & 600 & 330 & \multicolumn{4}{|c|}{ ONGOING } \\
\hline & & 600 & 330 & \multicolumn{4}{|c|}{ ONGOING } \\
\hline \multirow{6}{*}{$\mathrm{ESR}+\mathrm{HOMO}$} & \multirow{2}{*}{1050} & 600 & 330 & 745 & 13.23 & 13.50 & 18.21 \\
\hline & & 600 & 330 & 668 & 12.33 & 13.07 & 17.82 \\
\hline & \multirow{2}{*}{1100} & 600 & 330 & 2274 & 19.86 & 20.89 & 30.51 \\
\hline & & 600 & 330 & \multicolumn{4}{|c|}{ ONGOING } \\
\hline & \multirow{2}{*}{1150} & 600 & 330 & 2896 & 11.02 & 15.49 & 25.42 \\
\hline & & 600 & 330 & \multicolumn{4}{|c|}{ ONGOING } \\
\hline
\end{tabular}




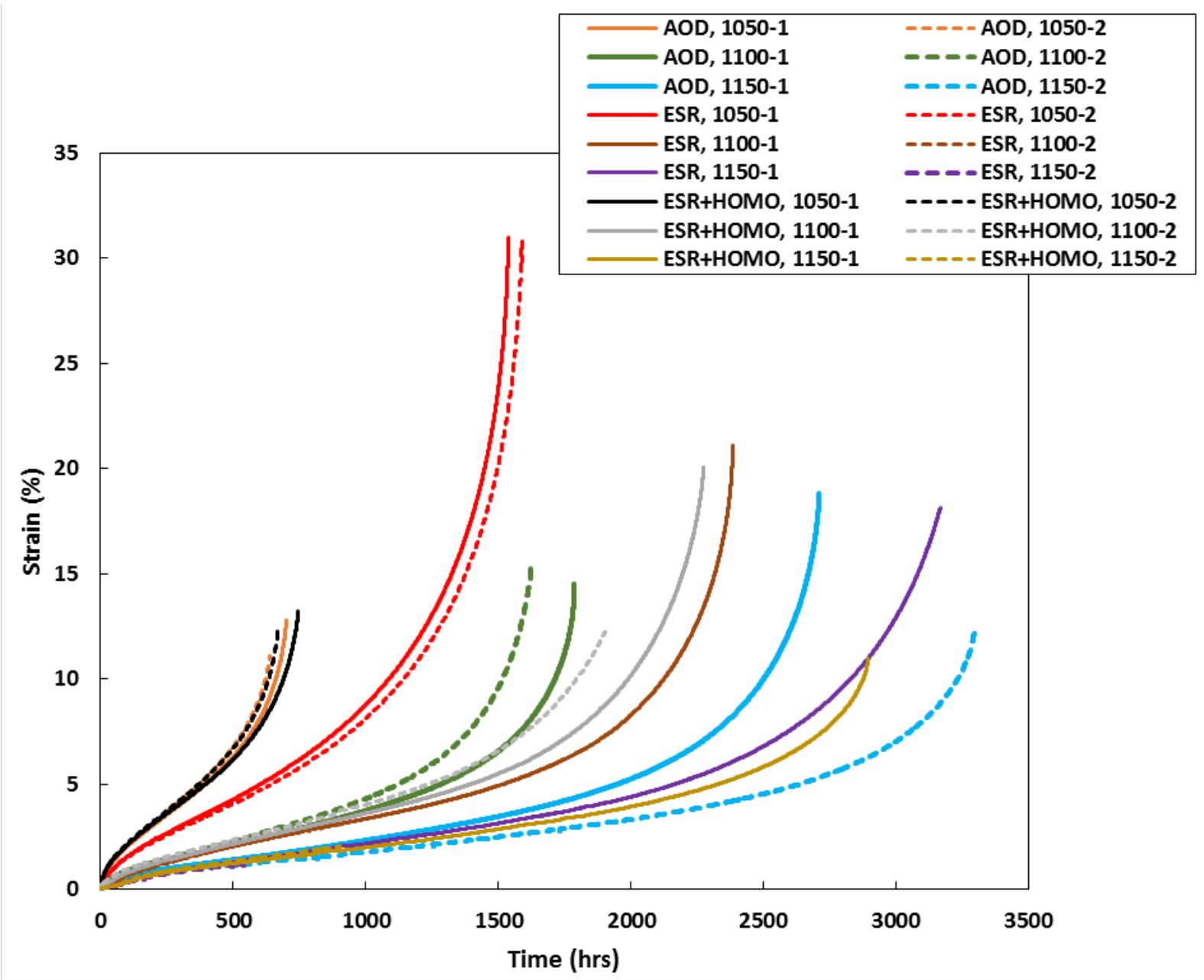

Figure 1. Creep curves for all preliminary 709 creep testing of the heat 58776-4.

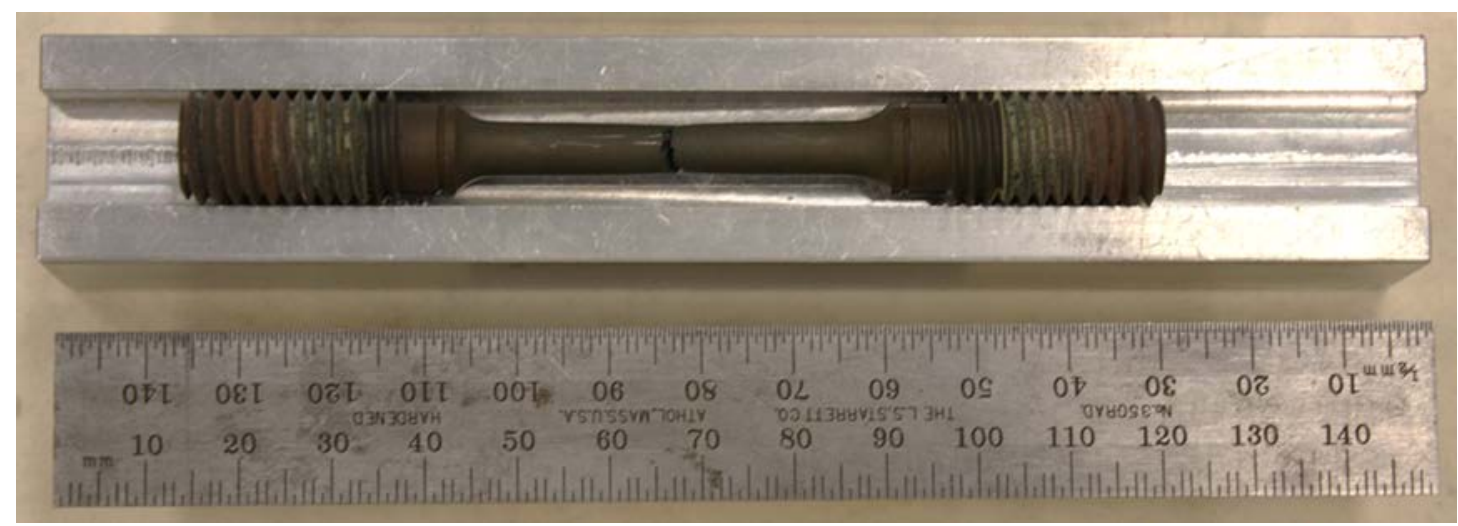

Figure 2. Example of a ruptured creep specimen. This is from the AOD S/A $1150^{\circ} \mathrm{C}$ plate.

In general, the differences between the processing conditions (AOD vs. ESR. vs. ESR+HOMO) are minor, with the exception of ESR at the $1050^{\circ} \mathrm{C}$ condition. ESR S/A $1050^{\circ} \mathrm{C}$ was found to have a much longer than expected rupture life and also to exhibit higher total elongation. The reason for the unexpected behavior is not clear at this time, but is being examined to determine whether the cause is microstructural based. 
The variation in creep properties with S/A temperatures is as expected. Creep properties tend to be poorer with decreasing grain size. The grain size is related to the S/A temperature. Higher annealing temperature results in larger grains. As an example of this, the grain size of AOD S/A $1050^{\circ} \mathrm{C}$ was found to be $23.9 \mu \mathrm{m}$ on average. At S/A $1100^{\circ} \mathrm{C}$, it was $31.7 \mu \mathrm{m}$ and at $\mathrm{S} / \mathrm{A} 1150^{\circ} \mathrm{C}$, it was $39.4 \mu \mathrm{m}$ on average. It is important to note that at the AOD S/A $1050^{\circ} \mathrm{C}$ condition, there was a bimodal grain distribution of very large $(\sim 800 \mu \mathrm{m})$ and very small grains $(\sim 20 \mu \mathrm{m})$, with about $60 \%$ of the surface area examined made up of large grains. The grain size distribution was fairly uniform for the S/A $1100^{\circ} \mathrm{C}$ condition, as well as the S/A $1150^{\circ} \mathrm{C}$ condition, though there were isolated large grains observed in the S/A $1150^{\circ} \mathrm{C}$ condition ( $\sim 20 \%$ of the surface area examined was made up of large grains). Example micrographs of the three S/A temperatures are depicted in Figure 3, Figure 4 and Figure 5.Similar grain-size increases with increasing S/A temperatures are expected for ESR and ESR+HOMO, though an in depth characterization was not performed.
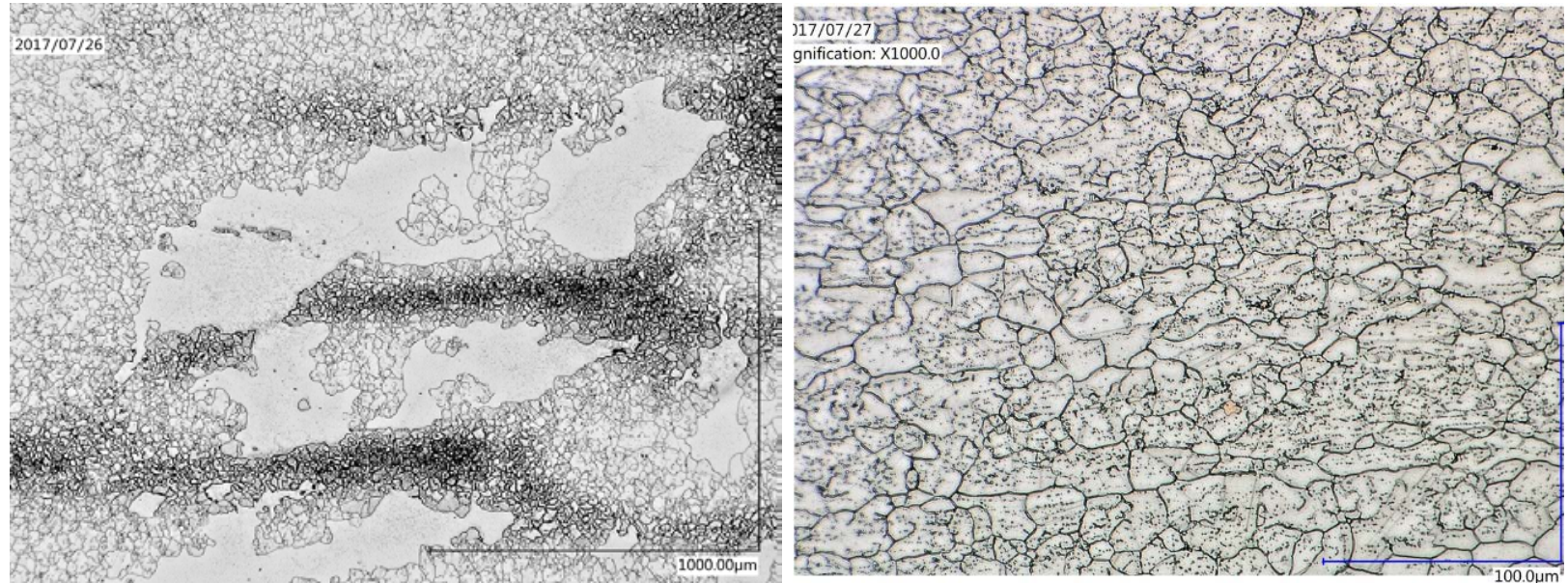

Figure 3. Example micrographs of the AOD S/A $1050^{\circ} \mathrm{C}$ plate. Grain distribution was bimodal, with both large grains and very small grains present.

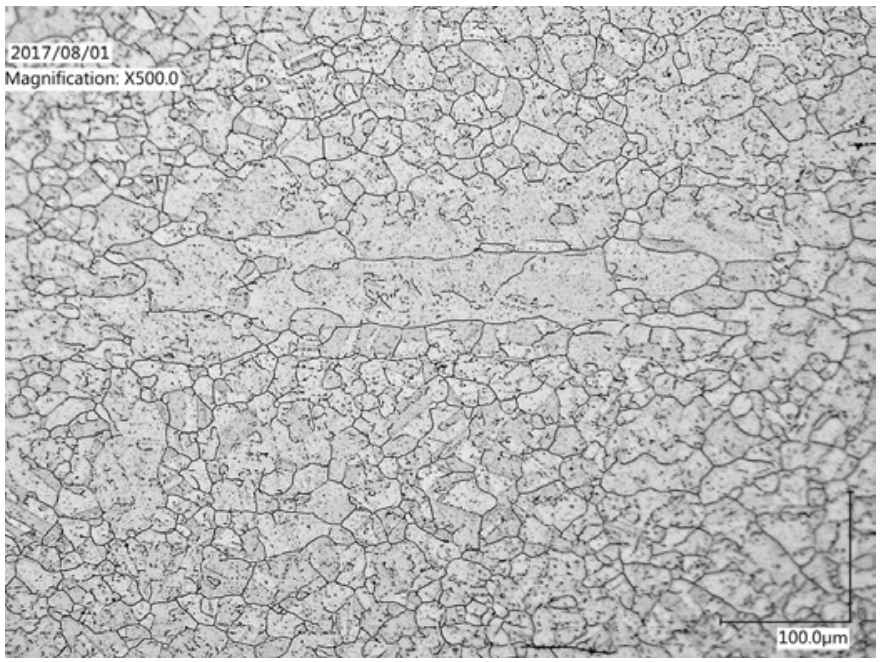

Figure 4. Example micrograph of the AOD S/A $1100^{\circ} \mathrm{C}$ plate. Grains were generally uniform in size. 

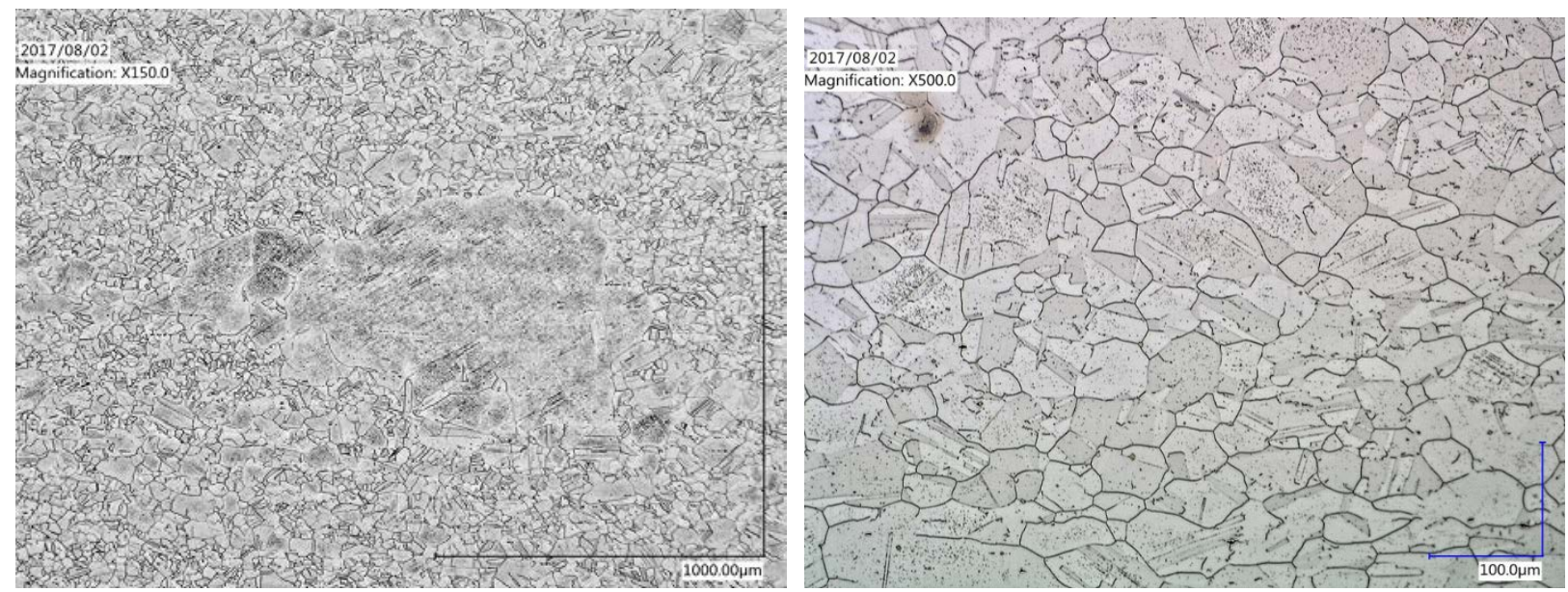

Figure 5. Example micrographs of the AOD S/A $1150^{\circ} \mathrm{C}$ plate. In general, grains were uniform in size, with the occasional large grain as seen in the left micrograph.

\subsection{Fatigue and Creep-Fatigue Results}

A total of 12 fatigue and 12 creep-fatigue tests were performed at Idaho National Laboratory (INL) on the heat 58776-4 plate of Alloy 709. This includes replicate tests performed for each AOD S/A condition, and single tests for the ESR and ESR+HOMO conditions. All testing has been completed, and the results are summarized in Table 3. Example mid-life hysteresis loops are shown in Figure 6, and all fatigue/creep-fatigue curves are shown in Figure 7.

The results of the fatigue testing exhibit some scatter. ESR, however, consistently has the poorest fatigue life at each condition tested, although in some cases, particularly the S/A $1150^{\circ} \mathrm{C}$, the difference is negligible, given the expected scatter in fatigue testing (note the large difference in life between the replicate AOD tests, particularly at the S/A $1150^{\circ} \mathrm{C}$ condition). AOD and ESR+HOMO are similar, except in the S/A $1100^{\circ} \mathrm{C}$ case, where the AOD plate was found to have significantly better fatigue life. Fatigue life is expected to be inversely related to grain size (smaller grains perform better), so the results are expected to follow an opposite trend compared to the creep results. This is not always the case in the tests performed here, however. ESR had a similar fatigue life across all three S/A temperatures.

$\mathrm{ESR}+\mathrm{HOMO}$ was the only condition that had the best fatigue life from the S/A $1050^{\circ} \mathrm{C}$ condition.

Creep-fatigue life is significantly shorter than fatigue life, as expected due to the creep damage occurring during the 30 minute tensile hold. For the AOD plate, the fraction of creep-fatigue to fatigue life remains fairly constant around 0.25 at all three S/A temperatures. For ESR, this fraction is slightly higher, around 0.30 , except for the S/A $1150^{\circ} \mathrm{C}$ condition, which drop to 0.19 . ESR+HOMO has the highest fraction at S/A 1050 and $1100^{\circ} \mathrm{C}(\sim 0.50)$, but drops severely at S/A $1150^{\circ} \mathrm{C}$ to 0.14 . The severe drop for $\mathrm{ESR}$ and $\mathrm{ESR}+\mathrm{HOMO}$ at $\mathrm{S} / \mathrm{A} 1150^{\circ} \mathrm{C}$ is undesirable. 
Table 3. Fatigue and creep-fatigue summary for Carlson alloy 709 testing.

\begin{tabular}{|c|c|c|c|c|c|c|}
\hline $\begin{array}{c}\text { Processing } \\
\text { condition }\end{array}$ & S/A & Temp. & Strain Rate & \begin{tabular}{|c}
$\begin{array}{c}\text { Hold time } \\
\left(t_{\mathrm{h}}\right)\end{array}$ \\
\end{tabular} & \begin{tabular}{|c|} 
Total strain \\
$\left(\Delta \varepsilon_{\mathrm{t}}\right)$ \\
\end{tabular} & \begin{tabular}{|c|c|} 
Cycles \\
to Failure
\end{tabular} \\
\hline & $\left({ }^{\circ} \mathrm{C}\right)$ & $\left({ }^{\circ} \mathrm{C}\right)$ & $(/ \mathrm{s})$ & (min) & (\%) & $\left(\mathrm{N}_{25}\right)$ \\
\hline \multirow{12}{*}{ AOD } & \multirow{4}{*}{1050} & 650 & 0.001 & 0 & 1.0 & 1683 \\
\hline & & 650 & 0.001 & 0 & 1.0 & 1440 \\
\hline & & 650 & 0.001 & 30 & 1.0 & 454 \\
\hline & & 650 & 0.001 & 30 & 1.0 . & 422 \\
\hline & \multirow{4}{*}{1100} & 650 & 0.001 & 0 & 1.0 & 1760 \\
\hline & & 650 & 0.001 & 0 & 1.0 & 1717 \\
\hline & & 650 & 0.001 & 30 & 1.0 & 497 \\
\hline & & 650 & 0.001 & 30 & 1.0 . & 367 \\
\hline & \multirow{4}{*}{1150} & 650 & 0.001 & 0 & 1.0 & 1954 \\
\hline & & 650 & 0.001 & 0 & 1.0 & 1391 \\
\hline & & 650 & 0.001 & 30 & 1.0 & 343 \\
\hline & & 650 & 0.001 & 30 & 1.0. & 462 \\
\hline \multirow{6}{*}{ HOMO } & \multirow{2}{*}{1050} & 650 & 0.001 & 0 & 1.0 & 1850 \\
\hline & & 650 & 0.001 & 30 & 1.0 . & 519 \\
\hline & \multirow{2}{*}{1100} & 650 & 0.001 & 0 & 1.0 & 1323 \\
\hline & & 650 & 0.001 & 30 & 1.0 . & 438 \\
\hline & \multirow{2}{*}{1150} & 650 & 0.001 & 0 & 1.0 & 1458 \\
\hline & & 650 & 0.001 & 30 & 1.0 . & 281 \\
\hline \multirow{6}{*}{$\mathrm{ESR}+\mathrm{HOMO}$} & \multirow{2}{*}{1050} & 650 & 0.001 & 0 & 1.0 & 1150 \\
\hline & & 650 & 0.001 & 30 & 1.0 . & 568 \\
\hline & \multirow{2}{*}{1100} & 650 & 0.001 & 0 & 1.0 & 1058 \\
\hline & & 650 & 0.001 & 30 & 1.0. & 534 \\
\hline & \multirow{2}{*}{1150} & 650 & 0.001 & 0 & 1.0 & 1318 \\
\hline & & 650 & 0.001 & 30 & 1.0. & 184 \\
\hline
\end{tabular}
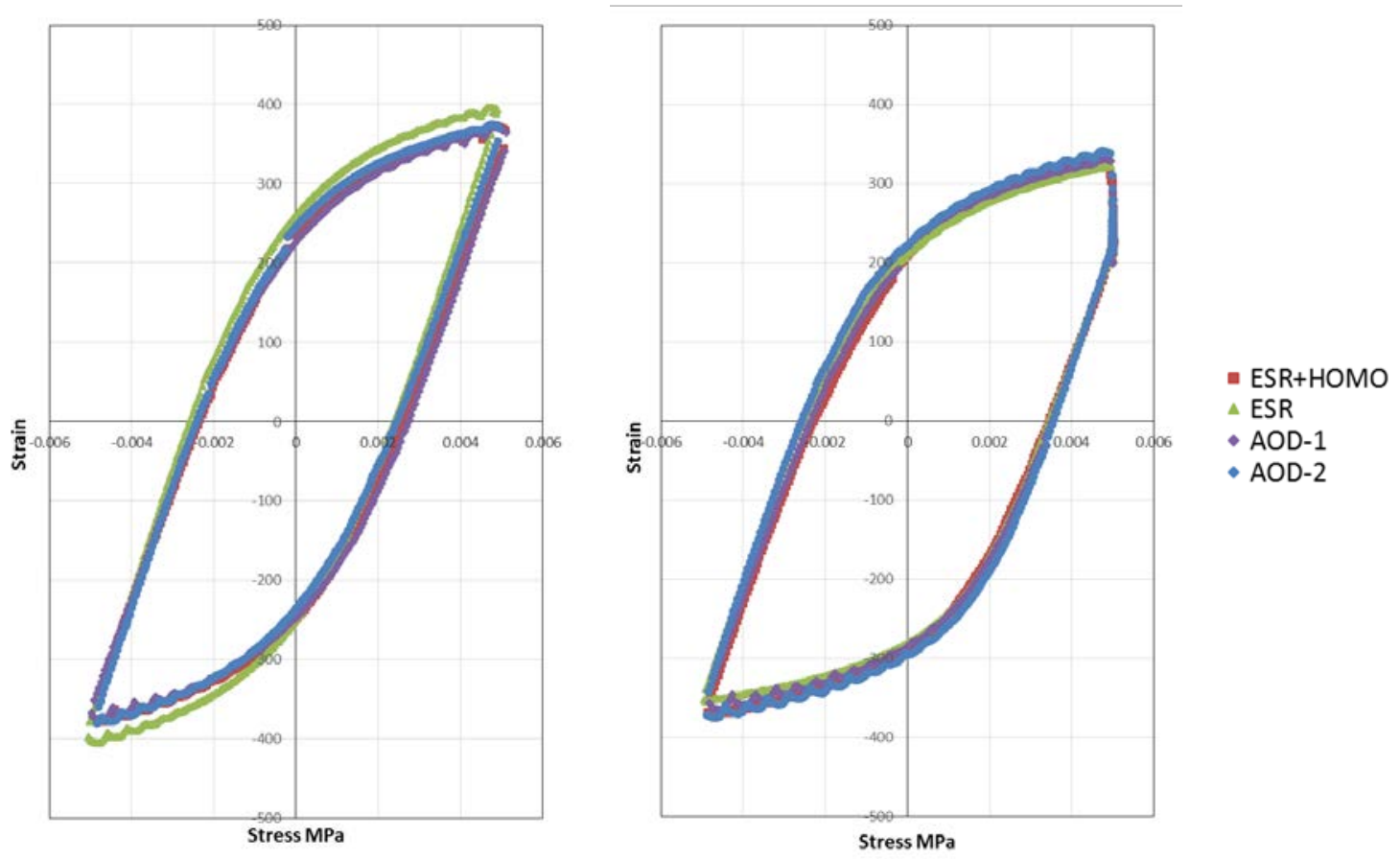

Figure 6. Examples of hysteresis loops. Fatigue (left) and creep-fatigue (right) mid-life hysteresis loops of the 709 plates in the $\mathrm{S} / \mathrm{A} 1100^{\circ} \mathrm{C}$ condition. 


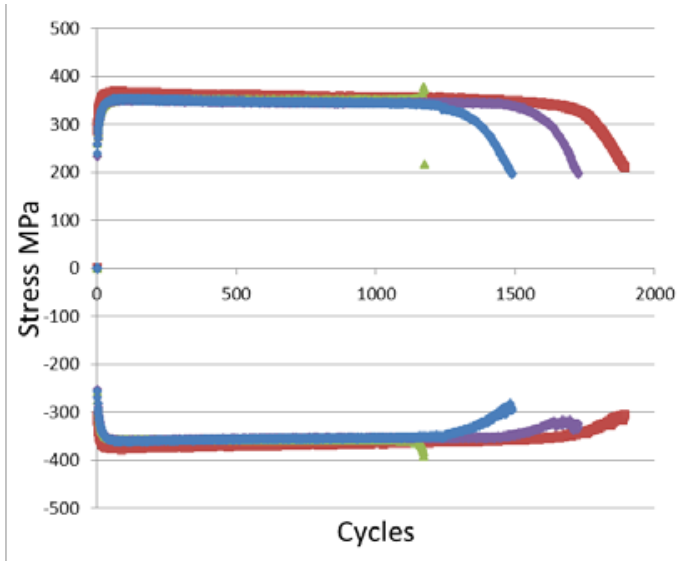

(a)

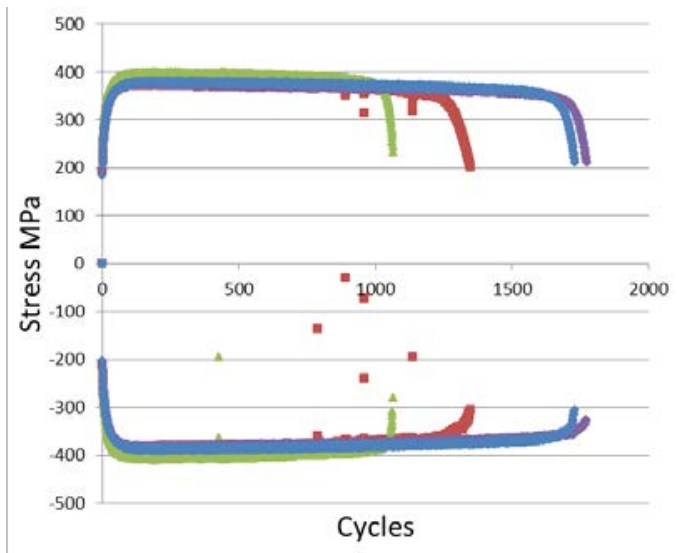

(c)

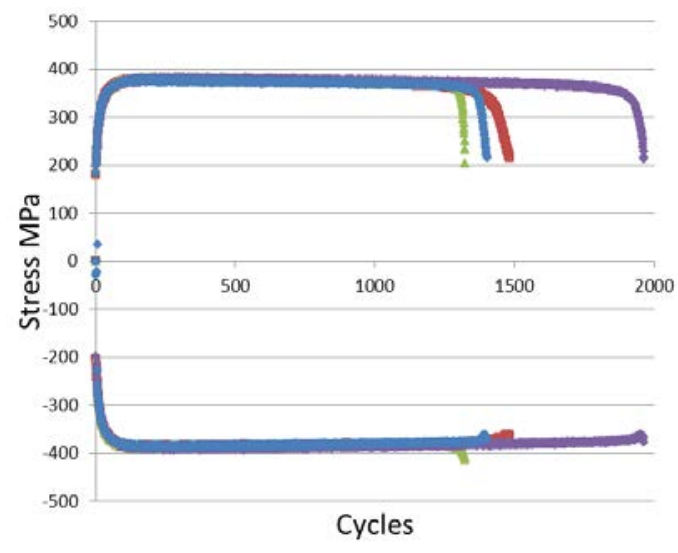

(e)

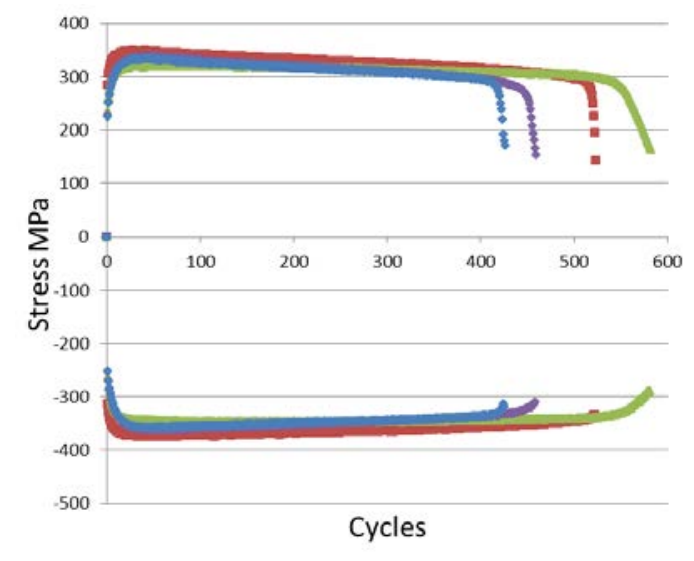

(b)

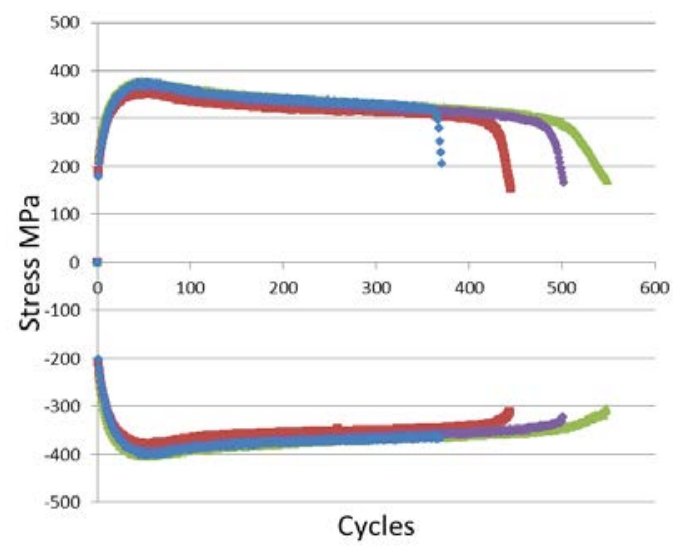

(d)

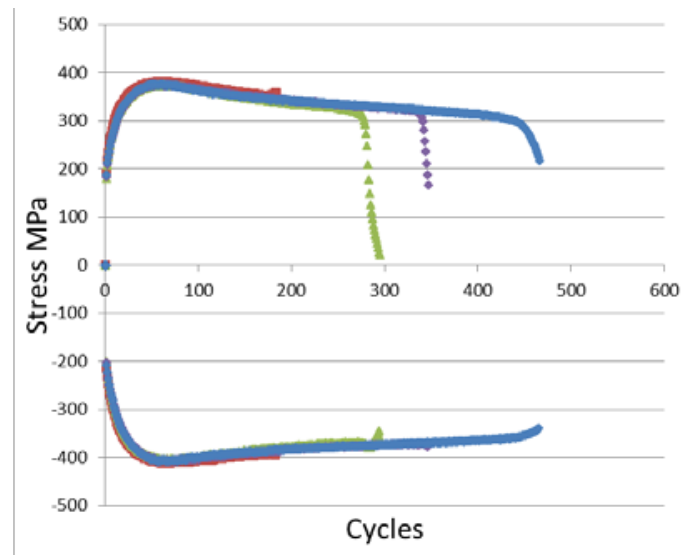

(f)

Figure 7. Fatigue (a,c,e) and creep-fatigue (b,d,f) curves for the S/A $1050^{\circ} \mathrm{C}(\mathrm{a}, \mathrm{b}), 1100^{\circ} \mathrm{C}(\mathrm{c}, \mathrm{d})$ and $1150^{\circ} \mathrm{C}(\mathrm{e}, \mathrm{f})$ conditions. 


\subsection{Combined Properties}

Determining best processing practices is complicated by the need to balance multiple properties. Creep and fatigue, in particular, tend to be affected by processing conditions in opposite directions with respect to the S/A temperature. Table 4 summarizes all the results from the previous sections, with replicate tests being averaged into one value. While there are no creep tests finished for the ESR S/A $1150^{\circ} \mathrm{C}$ condition, it appears, based on Figure 1, that the life will be similar to the other conditions (around 3300 hours for ESR 1150-1). Based on creep alone, the ESR condition appears superior. However, ESR had the poorest fatigue results. Creep-fatigue at $1150^{\circ} \mathrm{C}$ was also particularly bad for ESR, although it should be taken into consideration that there were no replicate tests performed for ESR or $\mathrm{ESR}+\mathrm{HOMO}$ for fatigue or creep-fatigue, so it is not possible to know if these values are reproducible. AOD and ESR+HOMO had similar creep properties, but the ESR+HOMO tended to do poorly in fatigue and creep-fatigue at S/A temperatures above $1050^{\circ} \mathrm{C}$.

Table 4. Summary of all mechanical testing. Replicate tests are averaged to one value.

\begin{tabular}{|c|c|c|c|c|c|c|c|c|c|}
\hline & \multicolumn{9}{|c|}{ Average Life } \\
\cline { 2 - 11 } & \multicolumn{3}{|c|}{ Creep (hrrs) } & \multicolumn{3}{c|}{ Fatigue (cycles) } & \multicolumn{3}{c|}{ Creep-Fatigue (cycles) } \\
\hline \multirow{2}{*}{ Plate } & $\begin{array}{c}\text { S/A } \\
1050^{\circ} \mathrm{C}\end{array}$ & $\begin{array}{c}\text { S/A } \\
1100^{\circ} \mathrm{C}\end{array}$ & $\begin{array}{c}\text { S/A } \\
1150^{\circ} \mathrm{C}\end{array}$ & $\begin{array}{c}\text { S/A } \\
1050^{\circ} \mathrm{C}\end{array}$ & $\begin{array}{c}\text { S/A } \\
1100^{\circ} \mathrm{C}\end{array}$ & $\begin{array}{c}\text { S/A } \\
1150^{\circ} \mathrm{C}\end{array}$ & $\begin{array}{c}\text { S/A } \\
1050^{\circ} \mathrm{C}\end{array}$ & $\begin{array}{c}\text { S/A } \\
1100^{\circ} \mathrm{C}\end{array}$ & $\begin{array}{c}\text { S/A } \\
1150^{\circ} \mathrm{C}\end{array}$ \\
\hline ADD & 670 & 1706 & 3004 & 1562 & 1739 & 1673 & 438 & 432 & 403 \\
\hline ESR & 1564 & 2386 & Ongoing & 1150 & 1058 & 1318 & 568 & 534 & 184 \\
\hline ESR+HOMO & 707 & 2274 & 2896 & 1850 & 1323 & 1458 & 519 & 438 & 281 \\
\hline
\end{tabular}

\section{SUMMARY}

Nine processing conditions and S/A temperature combinations of Alloy 709 were used to perform creep, fatigue, and creep-fatigue tests. In general, the lower S/A temperature $\left(1050^{\circ} \mathrm{C}\right)$ had poor creep performance, with the exception of the ESR processing condition. The high-temperature S/A condition $\left(1150^{\circ} \mathrm{C}\right)$ tended to have poor creep-fatigue life, with the exception of the AOD plate. The ESR plate has the best creep life, and the AOD plate tended to have the best fatigue life. The AOD or the ESR plates may be considered for future testing and, eventually, code qualification; however, there does not seem to be any substantial benefit gained by performing the addition homogenization processing step. Therefore, given that it is also an added expense when making the plate, there does not seem to be any benefit for progressing testing on the ESR+HOMO condition.

\section{FUTURE WORK}

Additional microstructural analysis will be performed on all plates and tested specimens. Current microstructural analysis has shown that the $1050^{\circ} \mathrm{C} \mathrm{S} / \mathrm{A}$ condition creates grains that are too small and fall outside of allowable grain sizes for this material. This restricts allowable S/A temperatures to just a $50^{\circ} \mathrm{C}$ window $\left(1100-1150^{\circ} \mathrm{C}\right)$. Additional heat treatments performed at INL on portions of the AOD asrolled plate were performed at 1075 and $1175^{\circ} \mathrm{C}$, with the goal of extending the allowable S/A temperature window to $100^{\circ} \mathrm{C}\left(1075-1175^{\circ} \mathrm{C}\right)$. Testing similar to that described in this report will be carried out on material given those heat treatments. An additional plate was solution annealed at $1150^{\circ} \mathrm{C}$ to compare the lab heat treatments performed at INL with the original G.O. Carlson AOD S/A $1150^{\circ} \mathrm{C}$ plate.

The data generated by INL, including the five remaining creep tests that are ongoing, will be combined with testing data from Oak Ridge National and Argonne National Laboratories. The additional test data will supplement the current testing results and allow for a final decision to be made on desired processing conditions to be moved forward for additional testing. 


\section{ACKNOWLEDGMENTS}

The research was sponsored by the U.S. Department of Energy, under Contract No. DE-AC0206CH11357 with Argonne National Laboratory, managed and operated by UChicago Argonne LLC. Programmatic direction was provided by the Office of Nuclear Energy.

The author gratefully acknowledges the support provided by Alice Caponiti, Director, Office of Advanced Reactor Technologies (ART), Sue Lesica, Federal Manager, ART Advanced Materials Program, Robert Hill of Argonne National Laboratory, National Technical Director, ART Fast Reactors Campaign, and Sam Sham of Argonne National Laboratory, ART Technology Area Lead on Advanced Materials.

The author acknowledges Richard Wright at Idaho National Laboratory for technical support, as well as Joel Simpson for support maintaining and running laboratory equipment.

\section{REFERENCES}

1. Y. Yamamoto, P. J. Maziasz, P.J., and T.-L. Sham, Report on the Optimization and Testing Results of Advanced Austenitic Alloys, ORNL/TM-2012/401 (2012) Oak Ridge National Laboratory, Oak Ridge, TN.

2. J. Wright, T. Lillo, L. and Carroll, Intermediate Term Creep-Fatigue Testing of Advanced Alloys, INL/LTD-15-36013 (2015) Idaho National Laboratory, Idaho Falls, ID.

3. L. J. Carroll and J. K. Benz, Intermediate-Term Creep-Fatigue Testing of Alloy 709 and Optimized Grade 92, INL/LTD-14-33022 (2014) Idaho National Laboratory, Idaho Falls, ID.

4. L. J. Carroll and J. K. Benz, Intermediate-Term Creep-Fatigue Testing of an Advanced Austenitic Alloy, INL/LTD-13-30219 (2013) Idaho National Laboratory, Idaho Falls, ID.

5. L. J. Carroll, and M. C. Carroll, Creep-Fatigue Behavior of Advanced Alloys, INL/LTD-12-26862 Rev. 1 (2012) Idaho National Laboratory, Idaho Falls, ID.

6. L. J. Carroll and J. K. Benz, Intermediate-Term Creep-Fatigue Testing of an Advanced Austenitic Alloy, INL/EXT-13-30219 (2013) Idaho National Laboratory, Idaho Falls, ID.

7. M. C. Carroll, and M. C. Carroll, Creep-Fatigue Behavior of Advanced Alloys, INL/LTD-12-26862 Rev. 1 (2012) Idaho National Laboratory, Idaho Falls, ID.

8. M. McMurtrey, L. Carroll, and J. Wright, Microstructural Effects on Creep-Fatigue Life of Alloy 709, INL/EXT-17-41079 (2017) Idaho National Laboratory, Idaho Falls, ID.

9. L. Tan, Y. Yamamoto, and T.-L. Sham, Materials Procurement and Related Examinations of Advanced Ferritic-Martensitic and Austenitic Alloys, ORNL/TM-2013/325 (2013) Oak Ridge National Laboratory, Oak Ridge, TN.

10. “Creep Fatigue Testing,” PLN-3346, Revision 9, (2017) INL/MIS-10-18953.

11. ASTM International, “Standard Test Method for Strain-Controlled Fatigue Testing,” E606-12 (2012).

12. ASTM International, “Standard Test Method for Creep-Fatigue Testing,” E2714-13 (2013).

13. “Creep Testing,” PLN-3386 Revision 2, (2016) INL/MIS-16-40783.

14. ASTM International, "Standard Test Methods for Conducting Creep, Creep-Rupture, and StressRupture Tests of Metallic Materials,” E139-11 (2011). 